\title{
Memetic Analysis on Construction of College English Translation Corpus
}

\author{
Jie Zhao \\ Science \& Technology College \\ North China Electric Power University (Baoding) \\ Baoding, China
}

\author{
Mengyuan Guo \\ English Department \\ North China Electric Power University (Baoding) \\ Baoding, China
}

\begin{abstract}
Nowadays, College English teaching fails to promote students' achievement in translation. The construction of College English Translation Corpus is necessary and helpful. Few studies have been taken on college English teaching through combining memetics and corpus which are complementary. From the perspective of memetics, the constructed College English Translation Corpus can be more beneficial for students to improve their translating skills.
\end{abstract}

Keywords-meme; corpus construction; college English translation corpus

\section{INTRODUCTION}

English translation Teaching is different from normal English teaching. Although in many universities English translation is one of the compulsory courses for English majors, it is not provided as a separate course to the non-English majors, having received inadequate attention in college English teaching [1]. It does not mean that it is less important for non-English majors to improve their translation skills. In fact, cultivating college students' abilities of translating plays a significant role in the college English course reform. Through observation to the practice in teaching, it is found that students can achieve little in the translation section of College English Test Band 4 and Band 6, even with basic language knowledge and potential for translation. Owing to limited teaching hours, teachers tend to involve few or not any aspects on translation, and related practice is far from enough. For students, they can only find materials with an original text and reference target text, which requires them to mechanically remember and fails to improve their flexibility in translating other materials. Furthermore, many errors are made by students repeatedly, uncorrected in time. All these reflect a gap between students' expectation to make progress in translation and their failure to acquire translating skills from English teaching.

\section{MEME AND CORPUS}

In 1976, British evolutionary biologist Richard Dawkins first coined the word meme in The Selfish Gene [2], as a concept for discussion of evolutionary principles in explaining the spread of ideas and cultural phenomena. Genes are basic units of evolution. The nature of genes is to replicate them. Like genes, memes are also replicators, which survive and change through the evolution of culture like the natural

This paper is supported by the Fundamental Research Funds for the Central Universities (No. 2015MS136): Studies and Cultivation of Undergraduates' Translation Competence from the Perspective of Pragmatics. selection of genes in biological evolution. Memes are presented as tunes, ideas, catch-phrases, clothes fashions, ways of making pots or of building arches, etc. and transmitted through imitation and replication from one mind to another [2]. Fidelity, fecundity and longevity are the three features of memes. And the whole process of meme replication includes assimilation, retention, expression and transmission. Language, as one of important carriers of meme, allows memes to exist through replication and transmission, and acts as a meme itself, which are presented as words, phrases, sentences and passages as well. The replication and transmission of memes benefit the development of language.

Corpus linguistic researchers believe that the corpus data are authentic and reliable. Corpus linguistics makes studies on the authentic natural language, which involves language memes as the widely replicated and transmitted part. Therefore, language memes can certainly be extracted from the corpus, and can certainly be taken as a component of the corpus [3]. Adopting the corpus as an auxiliary tool which has collected a large amount of authentic language material, users can make good use of advanced searching software to obtain needed data. It does not only bring benefit to English translation teaching, but also encourages students' independent learning. Today, there are few studies on college English teaching through combining memetics and corpus and many aspects to be further explored. This paper attempts to construct College English Translation Corpus which is dynamic and suitable for students' English level, to provide an access to improve their English translating skills.

\section{MEMETIC ANALYSIS ON CONSTRUCTION OF COLLEGE ENGLISH TRANSLATION CORPUS}

\section{A. Selection of Language Materials for College English Translation Corpus}

According to Memetics, successful language memes should be able to be perceived by receivers, obtain necessary attention and finally remain in receivers' mind. This kind of memes should be prominent enough to get receivers' attention, should be suitable within the limits of receivers' acquisition, and should be reliable to get receivers' trust[3]. Catering to the teaching object of college English teaching, i.e. non-English majors, the College English Translation Corpus is constructed with the aim to improve students' abilities and skills in applied 
translation but not literary translation, and to help students pass College English Test Band 4 and Band 6 (CET4 and CET6). It has selected the texts and translation exercises of New Horizon College English (Second Edition), the sections of translation in CET4 and CET6 of recent years and in practice tests with similar difficulty to CET4 and CET6. These materials are very familiar and practical to students, which are more likely to attract students' attention and meet their needs and acquisition limits as language memes, so that the College English Translation Corpus can better enhance the assimilation and language memes.

\section{B. Initial Construction of College English Translation Corpus}

College English Translation Corpus contains corresponding text in Chinese and English, taking Chinese version of the texts, reference answers to the translating exercises in the textbooks of New Horizon College English (Second Edition) and translation questions in CET4, CET6 and practice tests as the source language, taking the English version of the texts and standard reference answers as the target language. In addition, some students' translated work collected previously is also included. Although the parallel corpuses that can be searched online in China have played an important role in research and teaching of translation, the absence of comparison with the corresponding translated texts by students makes it less possible to reflect problems existing in students' translating process, which tends to result in lack of pertinence in English teaching [4]. Therefore, not only reference translated texts are provided, translation work done by students is also covered in College English Translation Corpus. It is pointed out in memetics that the longer language memes remain in the new receiver's mind, the more likely the memes are to be copied and transmitted to other receivers and then influence them [3]. The contrast between Chinese and English texts of the materials, together with the contrast between the reference translation and students' translated texts can be prominent enough to impress students when they are applying the corpus. Especially to the noted errors in students' translation, students tend to pay more attention, for the reason that the errors are often made by themselves, so that the correct corresponding translation can remain in mind much longer.

\section{Maintenance and Updating of College English Translation Corpus}

In the process of constructing College English Translation Corpus, it should be updated and complemented with students' newly translated texts. In English translation teaching, when students are required to translate new materials, they can withdraw language memes stored in memory and express in their translation. To update the corpus, not only successful translation done by students is contained, but also the texts reflecting common and typical errors in students' translation are included. Through the comparison initiatively done by students of their own work with others' and with reference translation, students are more likely to find out their problems and then try to get them solved, so that their translating skills get improved. This process is just the process of expressing and transmitting language memes. In the process of expression, students select memes needed to express, for which those preserved important related memes become a potential choice. And in the process of comparing and evaluating other students' translation, they choose to remember the language impressive to them, i.e. the motivational memes, which promotes transmitting the language memes. Meanwhile, by this means students constantly renew their own language memes and memorize them, so that their translating skills get improved.

\section{CONCLUSION}

On the whole, when establishing College English Translation Corpus, the theory of memetics is instructive for the selection of materials, the construction, maintenance and updating of the corpus. And the application of the corpus can also accelerate the assimilation of language memes in translation, strengthen the effect of memorizing the memes by students and promote expression and transmission of the memes, so that students' translating level can be actually improved.

\section{REFERENCES}

[1] Y.X. Wang, "On Some Problems in College English Translation Teaching," Chin. Transl. J. China, vol. 204, pp. 29-33, December 2010.

[2] R. Dawkins, "The Selfish Gene, " Oxford University Press, New York, 1976.

[3] D. L. Lai, R. F. Wen, "Corpus and Language Memes," Journal of Changsha Railway University(Social Science). vol. 14, pp. 156-157, June 2013 .

[4] J. Yu, C. H. Wang, "The Construction and Application of Teaching Oriented Translation Corpus Based on Comparative Teaching Method," Chin. Transl. J. vol. 203, pp. 59-64, October 2010. 